\title{
Sykepleie og ondskap
}

Det viktigste vi kan gjøre for å styrke sykepleierrollen og sykepleiens profesjonsetikk, er å fokusere på sykepleierens moralske og faglige autonomi

\section{Per Nortvedt}

Professor emeritus

Senter for medisinsk etikk, Universitetet i Oslo

Sykepleien 2015102 (53101) (e-53101)

DOI: 10.4220/Sykepleiens.2015.53101

Forrige gang skrev jeg om tyske sykepleieres deltakelse i Holocaust. Jeg beskrev hvordan det er godt dokumentert at sykepleiere i Tyskland deltok i alle deler av nazistenes utryddingsprogram: tvangssteriliseringene, og drapene på barn, handikappete og psykiatriske pasienter i eutanasiprogrammet.

Hva som er mest urovekkende ved dette er hvordan det kunne skje. Og det spørsmålet som kanskje er viktigst å besvare er hvordan forhindre at et tilsvarende sammenbrudd i profesjonsetikk skal kunne skje igjen.

\section{Kort vei til ondskap}

Det er mange forklaringer på hvordan sivilisasjonssammenbruddet kunne skje; historiske, kulturelle, ideologiske, politiske, sosialpsykologiske og maktteoretiske. Fra mitt synspunkt er imidlertid det mest gåtefulle og kanskje mest urovekkende to ting: For det første, mangel på empati.

Hvordan kan det være så lett «å skru» av dypt situerte og nedarvete motstandsmekanismer mot å påføre andre mennesker smerte og lidelse, så man til og med som sykepleier kunne være med på å gi barn smertefulle intrakardiale Fenolinjeksjoner, eller sulte dem i hjel på store sovesaler? Det er en gåte hvordan vi mennesker på den ene siden er forankret i en form for hverdagslig anstendighet, der vi stort sett oppfører oss ordentlig, er vennlige og imøtekommende og vil hverandre og også fremmede vel. 
På den andre siden er det avgrunner i oss vi nesten ikke kan våge å skue ned i. Og hvordan kunne dette med så stort omfang skje med sykepleien, som tross alt hadde en forankret etisk tradisjon i kristendom, nestekjærlighet og en lang diakonal barmhjertighetstradisjon i Tyskland.

\section{Kritisk refleksjon}

Hvordan legitimerte så sykepleieren mordene? En kombinasjon av kollektivistiske og økonomiske argumenter og lydighet overfor autoritetene viste seg å bli en dødelig blanding. Sykepleierne ble lært opp til å underordne hensynet til den enkelte pasient målsettingen om å bedre helsen til hele folket. På den andre siden oppga de tyske sykepleierne nesten alle som en lydighet som en viktig grunn for sin deltakelse i eutanasiprogrammet. Deres plikt var å følge legenes ordre.

Det var også respekt og lydighet overfor legen som overordnet sykepleierne dekket seg bak i sitt forsvar under rettsoppgjørene i tiden like etter krigen. Lydighet, ikke nazisme og ikke ideologi, var en av de viktigste grunnene til sykepleiernes ugjerninger. Hva sier det oss i dag? Jo, det sier oss at noe av det viktigste vi i dag kan gjøre for å styrke sykepleierrollen og sykepleiens profesjonsetikk, er å fokusere på sykepleierens moralsk og faglige autonomi.

Det innebærer å kunne tenke selv, nødvendigheten av å kritisere autoriteter og idealer man ikke tror på og samtidig å kunne gi gode grunner for kritikk og egne handlinger. Evnen til kritisk refleksjon sammen med en respekt for menneskeverdet til den enkelte pasient og pårørende er således sementen $\mathrm{i}$ profesjonsetikken. Etikk uten refleksjon og kritikk av illegitim makt, av undertrykking og lydighet og lojalitet for lojalitetens skyld, er ingen etikk. Dette må vi lære studentene, dette må vi innprente i hver enkelt vi i dag utdanner. Kanskje Jens Bjørnebos ord til «En ung mann som vil frem i verden» skulle henge på veggen i hver høyskole. Slik lyder de fire første vers:

«Det første bud er ganske lett. De som er flest har alltid rett.

Tenk alltid på hva folk vil si og ta den sterkestes parti.

Og tviler du så hold deg taus - til du ser hvem som fär applaus

Tenk nøye ut hva du bør mene. Det kan bli dyrt å stå alene».

\section{Eutanasi og ressursknapphet}

En av de viktigste grunnene til nazistenes tvangssterilisering av «uønskete individer» og til drapene i eutanasiprogrammet, var ikke eugeniske. De var heller ikke primært rasebiologiske eller antisemittiske, men de var i stor grad politiske og $\varnothing$ konomiske. Etter nederlaget i den første verdenskrig var det nedgangstider i Tyskland. Særlig var det i Weimarrepublikkens siste dager stor sosial nød og arbeidsløshet. 
Det var stor mangel på sykehussenger, og denne mangel på behandlingsplasser ble særlig akutt når krigen på Østfronten begynte å gå dårlig, når sykehusene ble bombet av de allierte og sårete soldater i tusener vendte hjem fra slagmarken. Skulle senger da brukes til dem som ikke var produktive og som bare la beslag på ressurser som ellers kunne komme befolkningen til gode?

Som historikeren Michael Burleigh sier, skal man huske på at noe av nazistenes mest inhumane politikk hadde sitt utspring i Weimarperiodens diskusjon om «the useless eaters», pasienten som fylte særlig de psykiatriske institusjonene og som la bånd på samfunnets effektive ressursutnyttelse. Senere, som Burleigh også påpeker, ble fysisk og psykisk utviklingshemmete drept for å spare penger og ressurser til den kommende krigen. Medisinske grunner ble fabrikkert for å legitimere drapene (Burleigh 1994).

Man skal ikke dra sammenlikninger for langt, men tanker slår en om hvor lett politikken og økonomien kan få forrang for etikken og hvor farlig det kan være å snakke om individer som uønskete, om det å bli gammel og syk som uverdig, eller om tilstander som belastning for pårørende. Særlig i krise og nedgangstider kan det man ikke trodde var mulig faktisk bli praktisk politikk. 